\title{
International comparisons of child injuries and prevention programs: recommendations for an improved prevention program in Germany
}

\author{
G Ellsäßer, R Berfenstam
}

\begin{abstract}
Objectives-To compare child injury mortality in Germany with that of four neighboring countries, and to examine injury prevention models in these countries with a view to improving prevention programs in Germany.

Methods-Based on official cause of death certificates, child injury mortality rates in Germany are compared with those of Austria, the Netherlands, Sweden, and Switzerland. The main structures and funding of injury prevention programs in these countries are described.

Results-In all five countries, mortality is highest among children aged 1-4 years for home and leisure accidents and drownings. Transport accidents are the main cause of death in the 5-14 age group. Mortality in both age groups has fallen significantly since 1980, most markedly in Sweden and the Netherlands.

Conclusion-Drawing on the injury mortality data and experience of the comparison countries, the following recommendations are proposed to further reduce home and leisure injuries among children in Germany: (1) establish a soundly funded, central institution responsible for child injury surveillance, research, and the coordination of injury prevention activities, (2) improve product control legislation, and (3) disseminate specific safety information to target groups and the general public.

(Injury Prevention 2000;6:41-45)
\end{abstract}

Brandenburg Regional Public Health Office, Germany

G Ellsäßer

Department of Public Health and Caring Sciences, University of Uppsala, Sweden R Berfenstam

Correspondence to: Dr Gabriele Ellsäßer, Brandenburg Public Health Office, Wünsdorferplatz 3,

15838 Wünsdorf, Germany (e-mail:

101.198605@germanynet.de) children and young adults between the age of 1 and 45 in Germany and in Europe as a whole. In this age group, there are more deaths caused by injuries than by cancer or cardiovascular diseases. ${ }^{12}$ Thus unintentional injury is a principal public health issue with wide ranging personal, social, and economic consequences. It is, however, still largely underestimated by the government and the public.
In Germany in 1995, 788 children were killed $^{3}$ and 218108 were hospitalized. ${ }^{4}$ Among the latter, 12947 were officially reported road traffic injuries. ${ }^{5}$ Childhood injuries have an immense economic impact on society. ${ }^{67}$ In Germany, an estimate of the economic consequences of injuries in the 1-14 age group puts the figures at 3.6 billion DM (equivalent to 1.97 billion dollars) for $1995 .{ }^{89}$ This figure takes into account injury mortality as well as the costs for ambulance services, medical treatment, and rehabilitation.

\section{Methods}

Mortality figures for children in the $1-4$ and 5-14 age groups are taken from the official statistics in each of the countries being compared. For analysis purposes, the data are presented in two main groups according to the International Classification of Diseases, ninth revision (ICD-9) codes: transport (E800$807,810-816,818-819,830-838,840-845)$ and home and leisure. The latter includes drownings (E817, E820-29, E 850-869, E880-918, E920-928).

\section{Results}

GERMANY

In $1995,8.4 / 100000$ children aged $1-4$ years were fatally injured compared with 5.1/ 100000 children in the 5-14 age group. Two thirds of the fatal injuries among the preschoolers occurred in or around the home or during leisure activities, and one third while using some means of transport. Among children in the 5-14 age group, transport was the main cause of injury deaths. Drowning deaths were three times higher in the younger age group (2.1 v 0.6/100000 for 5-14 year olds). Between 1980 and 1995 injury mortality for the whole age group $1-14$ years was more than halved: from 14.9 to $6.3 / 100000$.
CHILD INJURY MORTALITY IN THE OTHER FOUR COUNTRIES COMPARED WITH GERMANY In 1980, the Netherlands, Sweden, and Switzerland had lower mortality rates than those of Austria and Germany. In Germany, mortality 

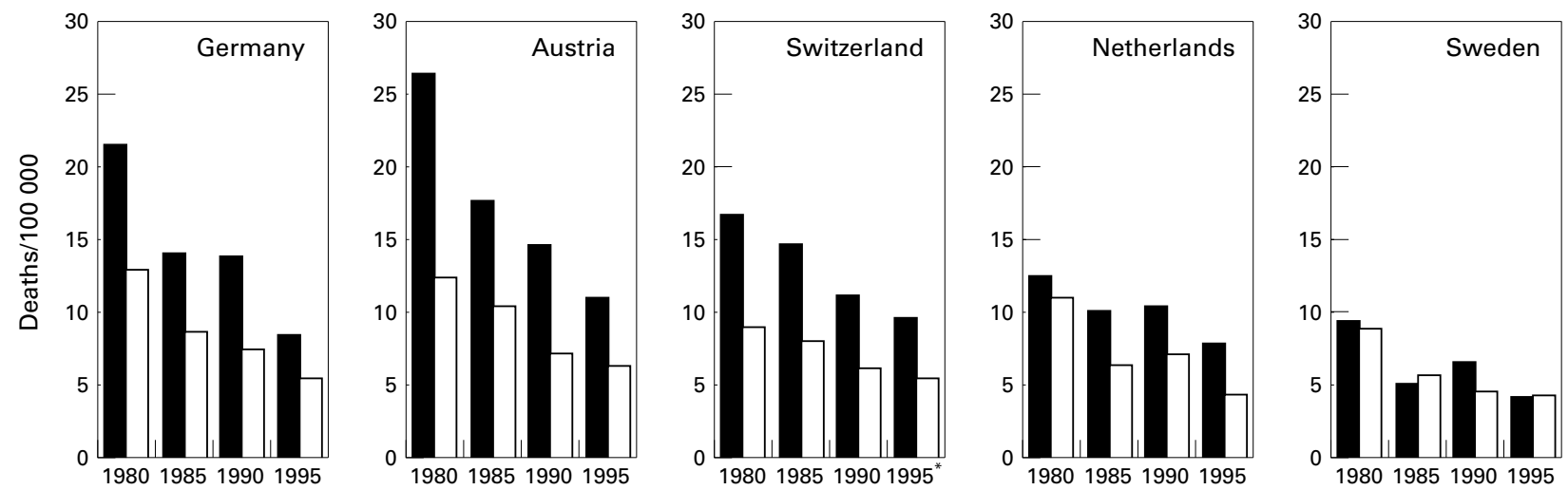

Figure 1 Overall injury mortality (E800-949) for children (1-4 and 5-14 years) in Germany compared with Austria, Switzerland, the Netherlands, and Sweden (1980-95). *ICD-10.

for children aged 1-4 years was between two and three times higher than in Sweden. There are, however, a number of common features between the picture in Germany and that in the other countries. In all the countries, mortality for both age groups has declined significantly since 1980 (fig 1). Death rates are higher among children aged 1-4 years both for home and leisure injury mortality and for drownings, whereas transport injuries are the main cause of death among children aged 5-14 years.

With regard to home and leisure injury mortality among children aged 1-4, Sweden has had the lowest rates of all five countries since 1980 (fig 2). In contrast, for transport injury mortality, there was a decline for both age groups in all five countries between 1980 and 1995 and the decline was most marked in Germany and Sweden (fig 3).

In 1995, drowning mortality in Sweden was-despite the large number of lakes and inland waterways-remarkably low compared with the other four countries. In the period studied, drowning mortality for children aged 1-4 years was three times higher in Germany than in Sweden.
Child injury prevention in Germany compared with the other four countries Unlike the other four countries, Germany has no central institution addressing the problem of home and leisure injuries that enjoys sound funding. Nor is there any body responsible for accident surveillance and research. Unlike Austria, no private insurance company provides support for prevention activities. Only since 1997 has Germany had two organizations active in the field of child safety. One is the German Federal Association for Child Safety, established as an initiative of the Federal Ministry for Health and sponsored by Johnson \& Johnson. The other is the German Green Cross, a non-governmental organization engaged in general child health issues.

These two organizations tackle the problems of child safety in different ways. The German Federal Association for Child Safety established a cooperative network of 28 organizations engaged in child health and safety to conduct information campaigns, particularly in the area of home and leisure injury prevention for children. The German Green Cross published the Childhood Accident Prevention Program ${ }^{10}$ based on epidemiological data. This program is
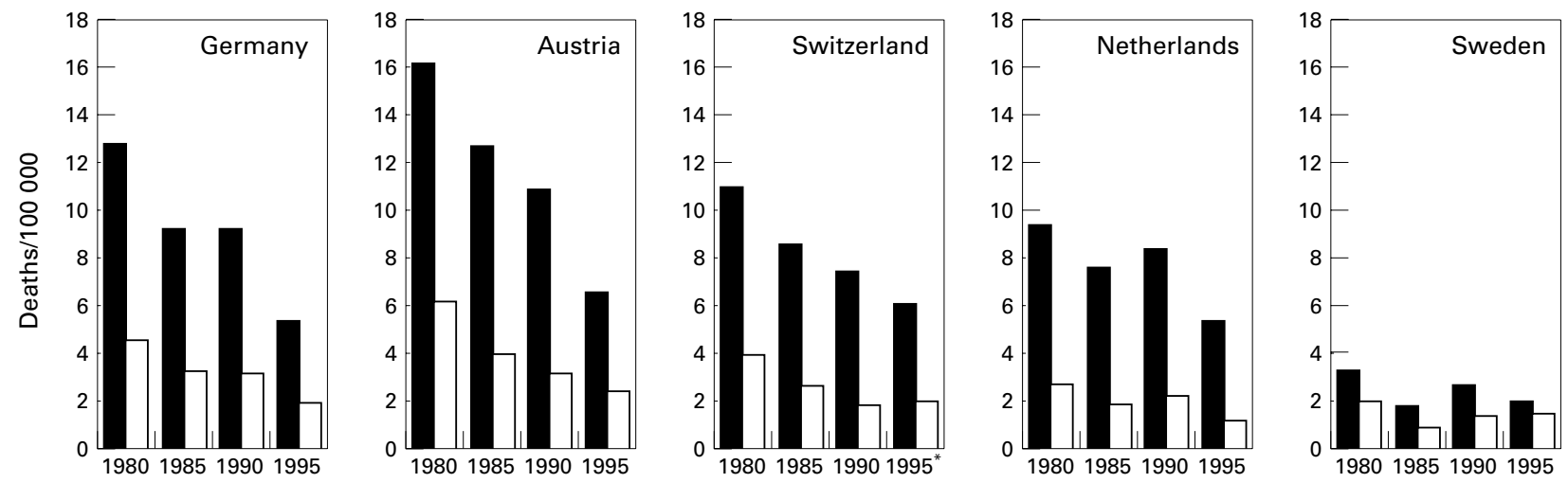

Figure 2 Home and leisure injury mortality (E817, E820-829, E850-869, E880-918, E920-928) for children (1-4 and 5-14 years) in Germany compared with Austria, Switzerland, the Netherlands, and Sweden (1980-95). *ICD-10. 

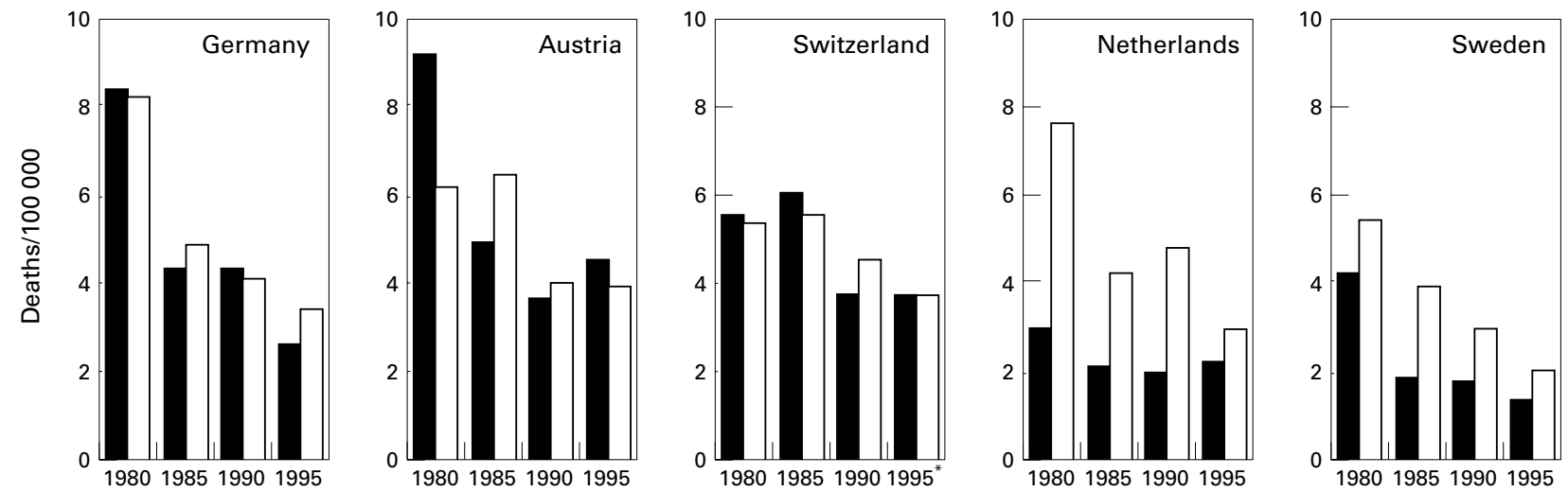

Figure 3 Transport injury mortality (E800-807, E810-816, E818-819, E830-838, E840-845) for children (1-4 and 5-14 years) in Germany compared with Austria, Switzerland, the Netherlands, and Sweden (1980-95). *ICD-10.

supported by professional medical associations and involves close cooperation with local bodies. Its goal is to intensify prevention efforts for home, traffic, leisure, and sports injuries as well as drowning.

Unlike Sweden and the Netherlands, however, until now Germany has not had a nationwide government run intervention program, ${ }^{11}$ except for road traffic accident prevention. This is the responsibility of the German Road Traffic Safety Council. ${ }^{12}$

By contrast, for the past 10 years in Austria, the Institut Sicher Leben (Safe Living Institute)-an organization acting in close cooperation with the Austrian Road Safety Board and the Austrian Workers' Compensation Board (responsible for safety in schools) has had a key role in the prevention of home, sport, and leisure injuries in all age groups. Importantly, most of the work of the institute is financed by the private insurance sector. There is close cooperation with regional "grass-roots" initiatives ("Safe Communities" funds), ${ }^{13}$ a continuous input of current research data on high risk groups, as well as an intensive exchange of information between all members of the National Safety Council (ÖSR), a national network of 56 institutions.

In the Netherlands, specific goals for accident prevention were defined by the government in a special memorandum issued in 1992 (1992 Gezondheid met Beleid). The Consumer Safety Institute, set up in 1983, was specifically commissioned and funded by the government. It is responsible for monitoring product safety and product safety standards. The goal is to minimize dangers in the environment, to prevent access to hazardous products (especially chemicals), and to reduce potential dangers by appropriate product design. ${ }^{14}$ In 1991, a national program was launched based on these principles with good results. ${ }^{15}$ Unlike the Swedish community oriented approach, the Dutch campaign largely targets specific groups. It is financed by the National Prevention Fund and supported by mass media campaigns.
Sweden has had a central organization and program for child accident prevention since 1954, and since 1993 the Barnombudsmannen (Children's Ombudsman), with the status of a government authority, has been responsible for the program. The Network for Safety of Children and Young People serves as an advisory body to the program. ${ }^{16}{ }^{17}$ To encourage multisectoral collaboration at the national, regional and municipal levels, and to work for safety in all age groups, the National Public Health Institute has established a national accident prevention program. ${ }^{18}$ This national program is complemented by local "Safe Communities" which are part of a World Health Organization network. ${ }^{19}$

The Swedish Child Accident Prevention Program relies on epidemiological data, legislation, ${ }^{20}$ the provision of information to key persons like planners, doctors, nurses, and teachers, and the dissemination of information on safety matters to the mass media and the public. ${ }^{21}$

In Switzerland, a national institution, the Swiss Council for Accident Prevention (CAP), has been responsible for injury prevention in all areas and for all age groups for the last 60 years. In 1984, CAP became a private foundation. It is well financed because the Swiss Accident Insurance Law stipulates that every Swiss citizen must have a non-occupational insurance policy to cover accidents during leisure activities. Altogether $0.75 \%$ of the total premiums paid is allocated to CAP, and this is supplemented by the Road Safety Fund.

The insurance law stipulates that CAP develop and implement prevention measures by providing information to various target groups, improving safety measures, influencing legislation, and by establishing a cooperative network. ${ }^{22}$ Additionally, regional and local safety delegates are elected by community councils every four years, or are appointed by community administrations. Beside their other tasks, these delegates act as CAP partners in disseminating information at the local level. They also supervise safety measures in the community. 


\section{Discussion}

LIMITATIONS OF AVAILABLE DATA

There are considerable difficulties associated with international comparative studies. When the comparison is based on cause of death statistics, the accuracy of death certificates and other records is of crucial importance. This problem is discussed at length elsewhere. ${ }^{23} \mathrm{It}$ should also be remembered that a comparison of death rates in countries with small child populations (1-1.5 million), and for specific years, as in this study, is problematic because of the liability to random fluctuations (for example, a school bus disaster, unpredictable weather related factors).

For the purposes of comparison, morbidity data would be a great help in evaluating the impact of different child injury prevention programs, but such data are sadly lacking. Hospital discharge registers are usually inadequate because the registering systems differ considerably. In Germany (since 1993) and Austria (since 1989, according to ICD-9), only diagnostic data are kept, whereas in both the Netherlands and Sweden additional information on the type and location of injuries is included. No data are available for Switzerland. Also, hospitalization rates reflect differences in medical care systems and in the availability of hospital beds. Additional morbidity data from the European Home and Leisure Accident Surveillance System (EHLASS), with a special focus on the consumer products involved in accidents, are only applicable for Austria, the Netherlands, and Sweden. ${ }^{24-26}$ Germany has declined to participate in EHLASS, drawing instead on a representative household survey on home and leisure accidents conducted by the Bundesanstalt für Arbeitsschutz und Arbeitsmedizin (Federal Institute for Occupational Safety and Health). These surveys have been conducted twice, once in $1989 / 90^{27} 28$ and again in $1996 .^{29}$

In addition to official mortality statistics, an estimate of morbidity-based on detailed annual statistics - is available only for the road traffic sector in all the countries studied. However, police involvement at the scene of an accident, the accuracy of the documentation, and the definition of an injured person vary greatly from country to country. It is therefore almost impossible to make proper international comparisons from these data.

Thus, cause of death records are the only official data that can serve as a basis for comparison. In order to perform proper surveillance and to develop a dynamic view of injury prevention-something that should be high on the agenda in Germany-more research and more data, especially on morbidity, are needed.

This overview has demonstrated that there are differences in child injury mortality among the countries studied and that positive trends have been discernable over the past 15 years. The refinement of emergency medical care, improvements in traffic as well as environmental and product safety, can be assumed to have contributed to these results. There are also differences in the structures, strategies, and strengths of the respective national prevention programs.

In some countries the basic conditions for prevention have improved-thanks, perhaps, to more sophisticated surveillance systems at the national and local level. What is striking is the different emphasis given and approaches adopted to child injury prevention in the countries considered. In Germany, for example, priority has been given to road injuries and to product safety standards (for example, toys, playground and nursery equipment, child resistant containers). Other countries have had greater successes by combining regulations on product safety with market controls at the local level (the Netherlands, Sweden) or through regulations on child safety standards in newly built homes (Sweden).

However, we are unable, on the basis of the material presented, to decide-according to scientific criteria-which country has the "best" national program or the most effective national structures for implementing safety policies. Nor is it possible to determine which elements of a prevention program are most effective.

We assume, however, that there is a relationship between soundly funded and well designed national child injury prevention programs, combined with local networks, and the number of lives saved. Examples include the reduction in road traffic injuries in Germany since 1985; the remarkable drop in home and leisure injuries in Austria since 1990; and the low level of drowning in Sweden since 1980. In the latter instance, special emphasis was placed on swimming instruction, the use of lifebelts, and the supervision of safety at pools, wells, and ponds. Regulations on product safety may be a factor in the decline of home and leisure injury mortality in all five countries.

Although all of the countries have witnessed a reduction in injury mortality for children aged 1-14 years, Sweden has the lowest rates overall, and, in particular, an extremely low rate of home and leisure injury mortality. If Germany wishes to keep step with the best ranking country, it will need a more comprehensive, government funded prevention program that recognizes injuries as a major public health issue. Drawing on the experience of the other countries and Germany's experience in road traffic injury prevention, we offer the following recommendations for improving the injury prevention program for children in Germany and elsewhere:

(1) In close collaboration with established national organizations, a well funded central organization should be established to coordinate child injury prevention measures at the national level and to assume responsibility for surveillance and research. This would promote the implementation of a nationwide program as a long term strategy.

(2) There should be close cooperation between the existing national network and emerging local alliances (for example, under the auspices of the German Green Cross) to intensify child safety efforts. 
(3) Child safety legislation including product control should be strengthened.

(4) Information should be provided personally and directly to target groups and as part of general health promotion. The medical care sector, as well as social workers at youth welfare offices, could play an important part.

(5) The mass media must be encouraged to put injury prevention on their agenda.

We wish to thank the following institutions that were particularly helpful to us in preparing our study-Germany: Federal Statis-
tical Office, German Green Cross, Brandenburg Public Health tical Office, German Green Cross, Brandenburg Public Health the Netherlands: Consumer Safety Institute; Sweden:The Children's Ombudsman; and Switzerland: Swiss Council for Accident Prevention.

1 Bertollini R, Dora C, Krzyzanowski M, et al. Environment and health. 1. Overview and main European issues. Copenhagen: World Health Organization Regional Office for Europe. WHO regional publications. European series 1996: 68

2 Rogmans WHJ. Preventing accidents in childhood: a European perspective. Acta Paediatr fpn 1993;35:215-22.

3 Statistisches Bundesamt. Todesursachen in Deutschland 1995. Wiesbaden: Statistisches Bundesamt 1996, Fachserie 12, Reihe 4.

4 Statistisches Bundesamt. Gesundheitswesen. Diagnosedaten der Krankenhauspatienten 1995. Wiesbaden: Statistisches Bundesamt 1997, Fachserie 12, Reihe 6.2.

5 Statistisches Bundesamt. Kinderunfälle im Straßenverkehr 1995. Statistisches Bundesamt 1997, Fachserie 8, Reihe 7.

6 Schlintl E, Goethals B. Kinderunfälle in Haushalt, Freizeit und Sport. Ergebnisse einer österreichischen Studie. Wien: Institut Sport. Ergebnisse einer österreichischen Studie. Wien: Institut

7 Roberts I, DiGuiseppi C, Ward H. Childhood injuries: extent of the problem, epidemiological trends, and costs. Inj Prev 1998;4(suppl):17-25.

8 Bensch B. Gesamtwirtschaftliche Auswirkungen der Unfälle in den Bereichen Heim, Freizeit und Sport. Wien: Institu "Sicher Leben" des Kuratorium für Verkehrssicherheit, 1995.

9 Bauer R. Kostenberechnungsmodell von Kinderunfällen. Wien: Sonderauswertung des Institutes "Sicher Leben" des Kuratorium für Verkehrssicherheit, 1998.

10 Deutsches Grünes Kreuz. Aktionsprogramm Prävention von Kinderunfällen. Marburg: DGK, 1997.

11 Ellsäßer G, Berfenstam R. Analyse von Kinderunfällen (1-14 Jahre) verknüpft mit Präventionsempfehlungen. Deutschland im Vergleich zu den models of good practice in den Niederlanden und Schweden. Zentralbl Kinderchir 1998;7:183-95.

12 Bundesministerium für Verkehr. Sicherheit im Straßenverkehr. Bericht über Maßnahmen auf dem Gebiet der
Unfallverhütung im Straßenverkehr und über das Rettungswesen in den fahren 1992 und 1993. Bonn: Bundesministerium für Verkehr, Bundesdrucksache 12/8335, 1994.

13 Goethals B, Kisser R, Rein F. Die Initiative "Sichere Gemeinden" 1993-1996. Wien: Institut Sicher Leben des Kuratoriums für Verkehrssicherheit und Sozialversicherungsanstalt der Bauern, 1997.

14 Ministry of Health, Welfare and Sport. Dutch policy on the prevention of accidents in the private domain. Rijswijk: 11 Documentation, 1998.

15 Rogmans WHJ. Acitvities, methodes, organization. Amsterdam: Stichting Consumenten Veiligheid, 1993

16 Berfenstam R. Kinderunfälle: was wirkt? Gute Erfahrungen aus Schweden. Brandenburgisches Ärzteblatt 1998;5:184-7.

17 Bergman AB, Rivara FP. Sweden's experience in reducing childhood injuries. Pediatrics $1991 ; 88: 69-74$.

18 Sweden's National Institute of Public Health. Strategies for success. National and local strategies for prevention of accidents and injuries. Stockholm: Sweden's National Institute of Public Health, 1994.

19 World Health Organization Collaborating Centre on Community Safety Promotion. A safe community. Stockholm: Karolinska Institutet, 1998.

20 Berfenstam R, Söderqvist IL. The rights of children to a safe environment. Swedish Laws and Regulations. Stockholm: National Board for Consumer Policies and National Child Environment Council, 1992.

21 Berfenstam R, Vahlquist B. Die Bedeutung des Unglücksfalles als Todesursache bei Kindern. Zeitschrift für Kinderheilkunde 1955;76:489-500.

22 Schweizerische Beratungsstelle für Unfallverhütung. BfuSicherheits-Kompass 2000. Bern: Schweizerische Beratungsstelle für Unfallverhütung, 1998 .

23 Mulder S. International trends and comparative studies. Edinburgh: 2nd European Convention in Safety Promotion and Injury Prevention 1990, abstracts 1999.

24 National Board of Health and Welfare and Swedish Consumer Agency. European Home and Leisure Accident Surveillance System. Annual report-Sweden 1997. Stockholm: National Board of Health and Welfare and Swedish Consumer Agency, 1998.

25 Consumer Safety Institute. EHLASS annual report 1997, the Netherlands. Amsterdam: Consumer Safety Institute, 1998

26 Goethals B, Hittinger E. EHLASS Austria fahresbericht 1996. Wien: Institut "Sicher Leben" des Kuratorium für Verkehrssicherheit, 1997.

27 Zeifang K, Pfleiderer R. Unfallgeschehen in Heim und Freizeit. Repräsentativbefragung für die Bundesrepublik Deutschland. Dortmund: Bundesanstalt für Arbeitsschutz, Forschung 1990, Sonderschrift 30.

28 Zeifang K, Hötzel B. Unfallgeschehen in Heim und Freizeit. Repräsentativbefragung für die neuen Bundesländer. Dortmund: Bundesanstalt für Arbeitsschutz und Arbeitsmedizin, Forschung, 1993, Sonderschrift 33.

29 Schlude I, Zeifang K. Untersuchung von Geräteunfällen in Heim und Freizeit. Dortmund: Bundesanstalt für Arbeitsschutz und Arbeitsmedizin, 1998, Sonderschrift 51. 